Bangladesh J. Sci. Res. 29(2): 163-172, 2016 (December)

\title{
GROWTH AND YIELD PERFORMANCE OF SELECTED WHEAT VARIETIES UNDER WATER DEFICIT CONDITIONS
}

\author{
Erin Zaman*, M. Abdul Karim, Md. Nasimul Bari, Nurunnaher Akter and Jalal Uddin Ahmed ${ }^{1}$ \\ Department of Agronomy, Bangabandhu Sheikh Mujibur Rahman \\ Agricultural University, Gazipur-1706, Bangladesh
}

\begin{abstract}
Effect of water deficit stress on growth and yield of three wheat (Triticum aestivum) varieties, viz. BARI Gom 25, BARI Gom 26 and Sourav was studied. Water deficit lowered the light interception at anthesis in wheat. Under water deficit condition, the highest amount of PAR interception was recorded in BARI Gom 26. The reduction of leaf area index (LAI), crop growth rate (CGR), relative growth rate (RGR) and net assimilation rate (NAR) were less in BARI Gom 26. Water deficit conditions lowered the SPAD values in all the three wheat varieties. BARI Gom 26 showed less reduction, while BARI Gom 25 reflected the highest reduction in SPAD value under water deficit condition. Under water deficit condition the maximum number of spikelets/spike, 1000grain weight and HI were recorded in BARI Gom 26 and the minimum in BARI Gom 25. Under both control and water deficit conditions BARI Gom 26 gave the highest grain yield, while the lowest grain yield was obtained from BARI Gom 25.
\end{abstract}

Key words: Crop growth rate, relative growth rate, net assimilation rate, 1000-grain weight, selected wheat varieties

\section{Introduction}

Wheat (Triticum aestivum L.) is an important cereal crop that ranks first globally and second as a food grain in Bangladesh after rice. The yield of wheat, however, in Bangladesh is much lower than that of many wheat growing countries. One of the main reasons for low yield of wheat is due to its larger production under rainfed conditions. In Bangladesh wheat is grown in rabi season, which is characterized by very low or no rainfall (from November to March), after the harvest of aman rice with residual soil moisture. Since the rabi season is characterized by low rainfall and relatively high evaporative demand, drought acts as the most important determinant factor for wheat productivity. Very often the crop under rainfed conditions encounters water stress of varying degrees at different growth stages. Water stress can limit plant growth and yield by creating physiological disorders in plant processes. Since wheat is mostly grown under rainfed conditions and water shortage has negative impact on growth and development of the crop, it is important to quantify the extent of tolerance of tolerant and susceptible wheat varieties (Bazzaz 2013) under long term water shortage conditions. It is also necessary to analyze the impact of water deficit stress on the reaction of physiological activities of wheat varieties differing in their tolerance levels. The present study was thus, undertaken to analyze the effect of water deficit on changes in growth phenomena, and yield response in three wheat varieties, differing in response to water deficit stress (Bazzaz 2013).

*Author for correspondence: <erinzaman.bsau@gmail.com>. ${ }^{1}$ Department of Crop Botany, Bangabandhu Sheikh Mujibur Rahman Agricultural University, Gazipur-1706, Bangladesh. 


\section{Materials and Methods}

The field experiment was carried out at the research field of the Bangabandhu Sheikh Mujibur Rahman Agricultural University (BSMRAU), Salna, Gazipur from November, 2013 to March, 2014 on an upland soil. Laboratory analyses were carried out at the Department of Agronomy and Department of Soil Science. The planting materials were three wheat varieties, viz. BARI Gom 25, BARI Gom 26 and Sourav were used as planting materials. The varieties were selected based on their higher relative yield and some better physiological attributes under water shortage conditions (Bazzaz 2013). The experiment was conducted in split-plot design comprising two water regimes in main plot and three wheat varieties in sub-plot with four replications. The water regimes were control (no water stress throughout the growing season) and water deficit stress (irrigation was stopped after crown root initiation stage). The unit plot size consisted of 10 rows each of $3 \mathrm{~m}$ long having a row to row distance of $20 \mathrm{~cm}$ and block to block distance of $1.5 \mathrm{~m}$. Wheat seeds at the rate of $120 \mathrm{~kg} / \mathrm{ha}$ were sown in line with hand on November 21, 2013. Fertilizers were applied @ 100-60-40-20-1 kg/ha N-P-K-S in the form of urea, triple super phosphate, muriate of potash and gypsum, respectively (Bangladesh Agricultural Research Council 2012). Harvesting was done on 15 March, 2014. Measurement of moisture percentage from three different levels of soil was done. Light interception (LI) at the crop canopy was measured at panicle initiation stage. Leaf area index (LAI), crop growth rate (CGR), relative growth rate (RGR) and net assimilation rate (NAR), specific leaf weight (SLW), specific leaf area (SLA) and leaf weight ratio (LWR) at different growth stages were calculated. SPAD value was taken from middle portion of the fully developed flag leaf of the tagged plants. Data was collected on effective tillers $/ \mathrm{m}^{2}$, spike length, spikelets/spike, grains/spike, thousand grain weights. The recorded data were analyzed statistically using the computer package STATISTIX-10 program.

\section{Results and Discussion}

Water deficit stress reduced the soil water potential at both vegetative and anthesis stages. Moisture (\%) of soil was measured at three levels such as at $0-10 \mathrm{~cm}, 10-20 \mathrm{~cm}$ and at $20-30$ $\mathrm{cm}$. Then gradually moisture percentage reduced. The rate of declination under water deficit conditions was fast at $0-10 \mathrm{~cm}$ level than other levels (Fig. 1).

Light interception in wheat canopy: Under control condition, the highest amount of photosynthetically active radiation (PAR) interception was recorded in Sourav (85.98\%) which was statistically identical with BARI Gom 26 (85.91\%) and the lowest PAR was in BARI Gom 25 (84.68\%) (Fig. 2). However, under water deficit condition, the highest amount of PAR interception was recorded in BARI Gom 26 (82.45\%) which was statistically identical with Sourav (81.66\%) and the lowest in BARI Gom 25 (73.29\%). The reduction in the amount of PAR under water deficit conditions was probably due to the reduction of number and size of leaves of the plants. 


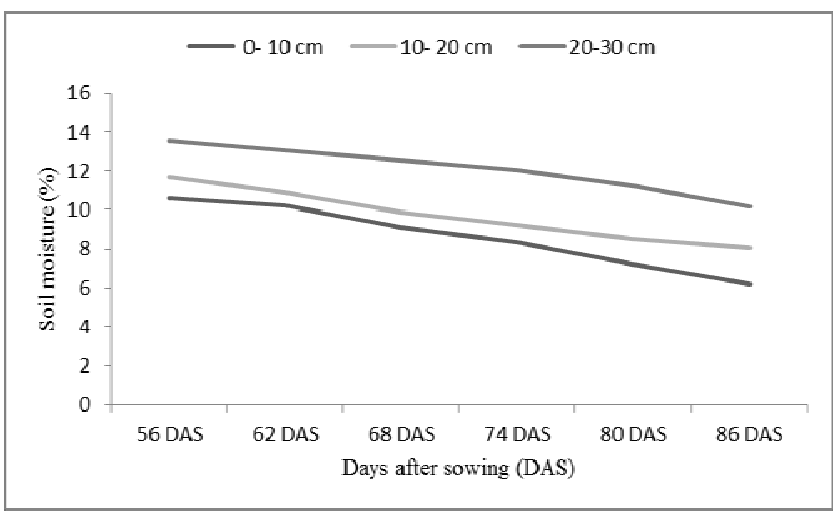

Fig.1. Moisture percentage at different level during crop growth of wheat under water deficit conditions.

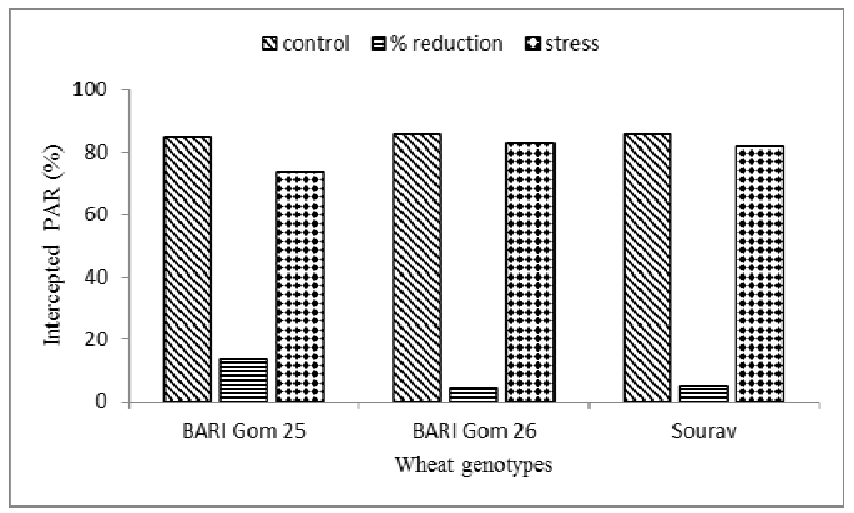

Fig. 2. Intercepted photosynthetically active radiation (PAR) in wheat canopy at anthesis under variable water regimes.

\section{Growth indices}

Leaf area index: LAI increased progressively from early growth stages of wheat and attained peak at (77 - 87) DAS under control and water deficit irrespective of varieties (Fig. 3). At peak, the maximum LAI ranged from 3.9 to 4.2 in BARI Gom 26, from 3.7 to 4.1 in Sourav and from 2.9 to 3.9 in BARI Gom 25 under control and water deficit conditions, respectively. BARI Gom 26 exhibited the maximum LAI. The initial increase of LAI in wheat was associated with tillering, higher leaf number and higher photosynthetic leaf surface area. The decline in LAI after attaining the peak might be due to senescence of leaves from the base of the stem approaching upward. Many studies are in line with the findings of the present study that drought at tillering stage (Hussain et al. 1987), during vegetative growth (Qadir et al. 1999) and at crown root plus booting stage (Qamar et al. 2011) caused reduction in LAI significantly in wheat than other irrigation treatments. 


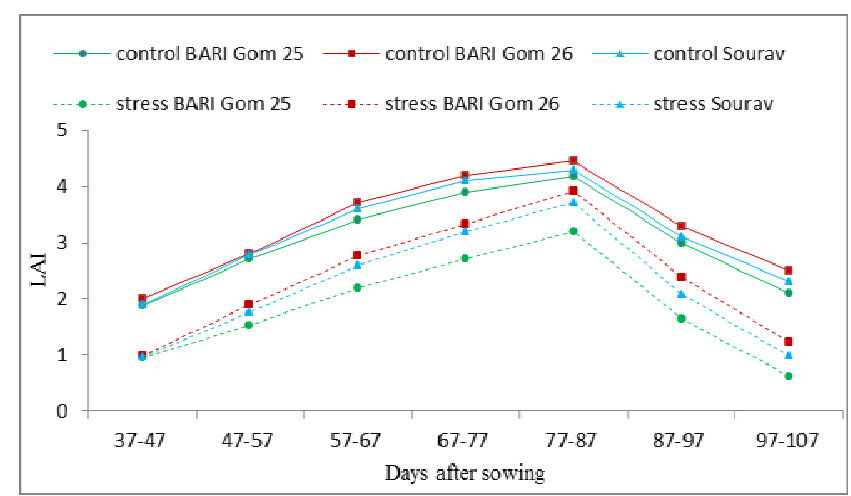

Fig. 3. Leaf area index in wheat varieties at different days after sowing under variable water regimes.

Crop growth rate: Under control and water deficit conditions, the maximum CGR was recorded at 87 DAS in all the varieties. At 87 DAS the CGR varied from 21.8 to 30.03 $\mathrm{gm}^{2} /$ day in BARI Gom 26, from 20.78 to $29.10 \mathrm{~g} \mathrm{~m}^{2} /$ day in Sourav, and from 15.68 to $28.11 \mathrm{~g}$ $\mathrm{m}^{2} /$ day in BARI Gom 25 under water deficit and control conditions, respectively. BARI Gom 26 maintained a good CGR throughout the growth period. It is an indication of drought tolerance, while the lowest CGR in BARI Gom 25 indicated its drought susceptibility. Reduction in CGR under water deficit stress conditions might be due to reduction in the LAI and the NAR. According to Akram (2011), moisture stress at different crop growth stages affected CGR differently.

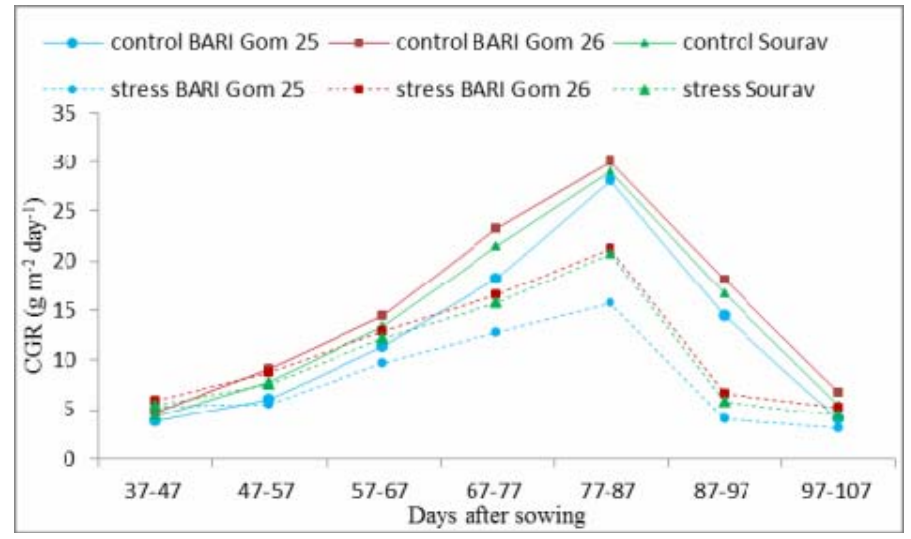

Fig. 4. Crop growth rate in wheat varieties at different growth period under water deficit conditions.

Relative growth rate: The RGR recorded at 47 DAS varied from 0.08 to $0.06 \mathrm{~g} / \mathrm{g} / \mathrm{day}$ in BARI Gom 26, from 0.07 to $0.06 \mathrm{~g} / \mathrm{g}$ /day in Sourav and from 0.07 to $0.05 \mathrm{~g} / \mathrm{g} /$ day in BARI Gom 25 under control and water deficit conditions, respectively. The highest RGR in BARI Gom 26 under water deficit is an indication of their drought tolerance, while the lowest RGR in BARI 
Gom 25 indicated its drought susceptibility. The reduction in the accumulation of dry matter and CGR under water deficit condition could be the result of a reduction in the RGR.

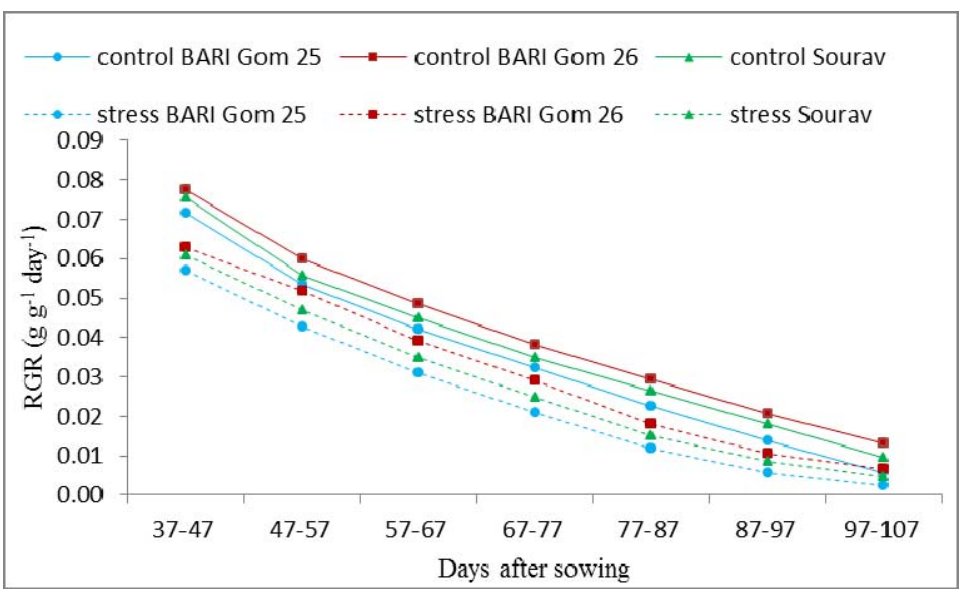

Fig. 5. Relative growth rate in wheat varieties at different growth period under variable water regimes.

Net assimilation rate: The maximum NAR varied from 3.23 to $3.45 \mathrm{~g} / \mathrm{m}^{2} /$ day in BARI Gom 26, from 3.16 to $3.35 \mathrm{~g} / \mathrm{m}^{2} /$ day in Sourav and from 2.98 to $3.15 \mathrm{~g} / \mathrm{m}^{2} /$ day in BARI Gom 25 under control and water deficit conditions, respectively. However, under control and drought the differences in NAR were conspicuous among the varieties. This might be due to early senescence of leaves.

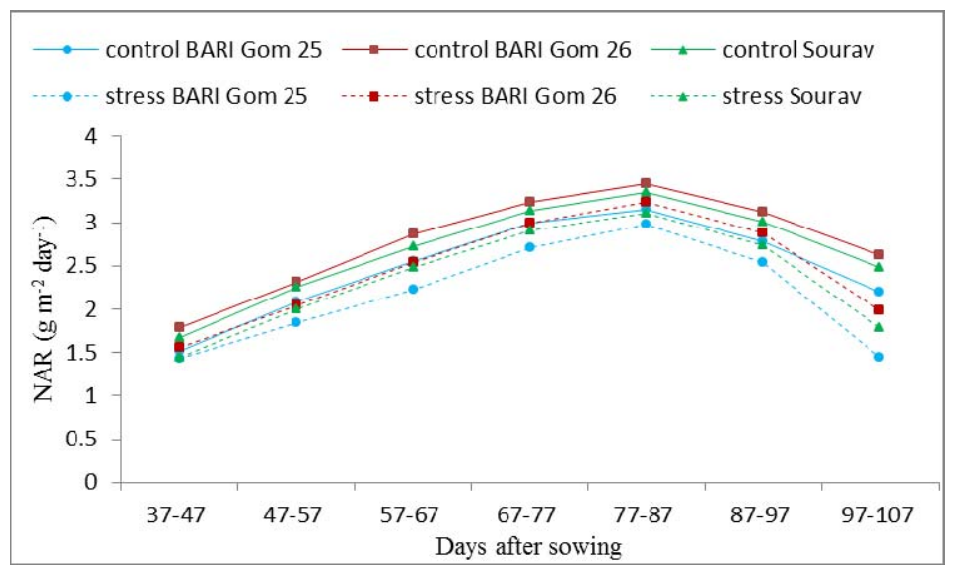

Fig. 6. Net assimilation rate in wheat varieties at different days after sowing under variable water regimes.

Specific leaf weight: The highest SLW was obtained in BARI Gom 25 which was followed by the varieties Sourav and BARI Gom 26 throughout the crop growth periods (Fig. 7). This 
thickness of leaf per unit area and also leaf rolling which decreased photosynthetic leaf surface than leaf weight might be the cause of higher SLW under water deficit condition at later stages.

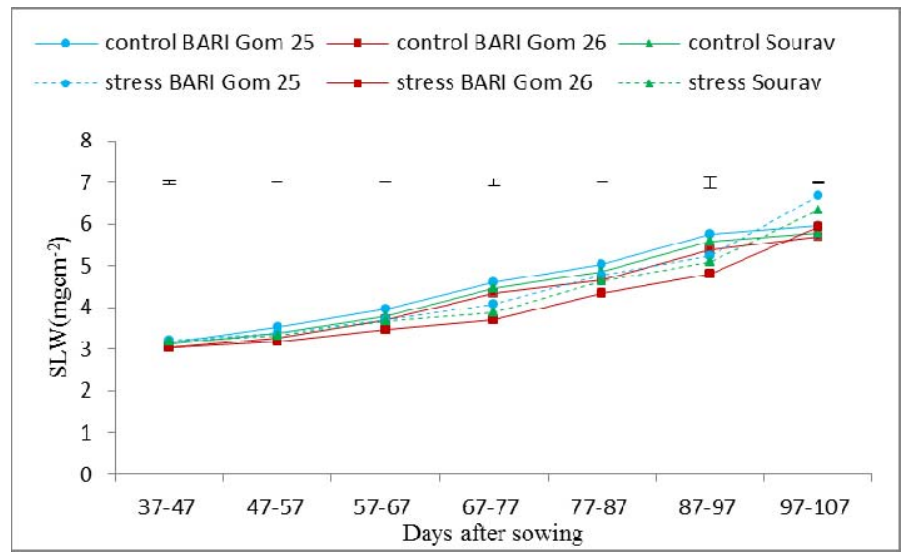

Fig. 7. Specific leaf weight in wheat varieties at different growth period under variable water regimes.

Specific leaf area: The maximum SLA noted at 47 DAS which varied from 315.4 to 330.4 $\mathrm{cm}^{2} / \mathrm{g}$ in BARI Gom 26, from 301.4 to $327.4 \mathrm{~cm}^{2} / \mathrm{g}$ in Sourav, and from 289.2 to $325.1 \mathrm{~cm}^{2} / \mathrm{g}$ in BARI Gom 25 (Fig. 8) under control and water deficit conditions, respectively. The lower SLA in BARI Gom 25 under water deficit condition might be due to early leaf senescence and translocation of assimilates from the leaves to the sink organs.

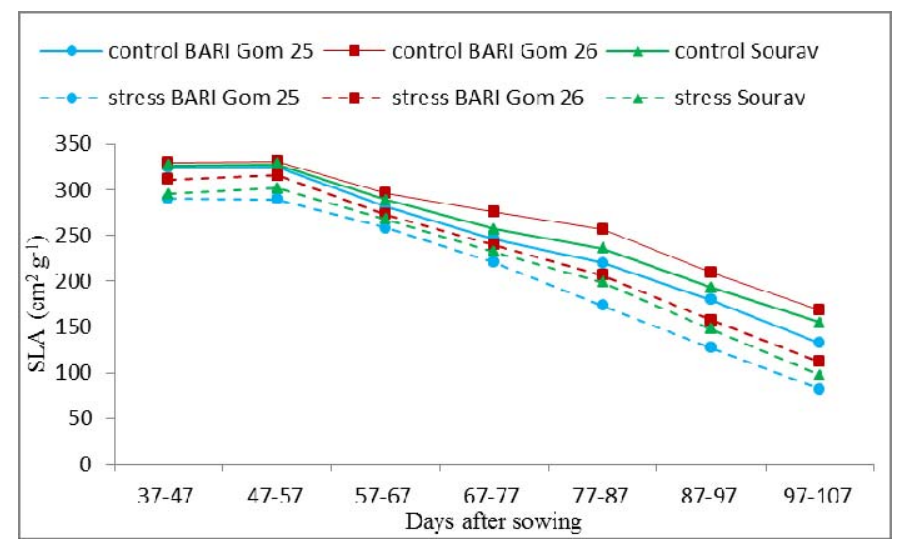

Fig. 8. Specific leaf area in wheat varieties at different growth period under variable water regimes.

Leaf weight ratio: There was a significant variation in LWR in three wheat varieties over time under variable water regimes as shown in Fig. 9. The maximum LWR under control was recorded in BARI Gom 26 as compared to and Sourav and BARI Gom 25 throughout the crop growth period. Under water deficit condition the highest LWR was obtained in BARI Gom 26 
which was followed by Sourav and the lowest in BARI Gom 25 throughout the crop growth period. The lower LWR in three wheat varieties under water deficit at 93 DAS might be due to early senescence of leaves.

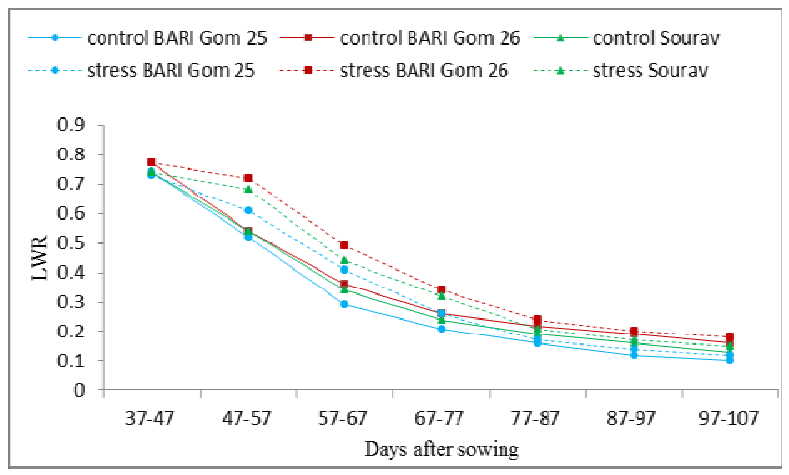

Fig. 9. Leaf weight ratio in wheat varieties at different growth period under variable water regimes.

The SPAD reading was taken from anthesis to physiological maturity stages in fully expanded flag leaf at 5-day intervals (Fig. 10). Under water deficit condition, the rate of decrease in SPAD value was higher in BARI Gom 25 and lower in BARI Gom 26 which was followed by Sourav. The result also indicated that the rate of decrease in SPAD value at later stages was higher under water deficit condition than that of control. Water deficits enhanced the senescence by accelerating loss of leaf chlorophyll and soluble proteins and the loss was more in sensitive one than tolerant one (Saeedipour 2012).

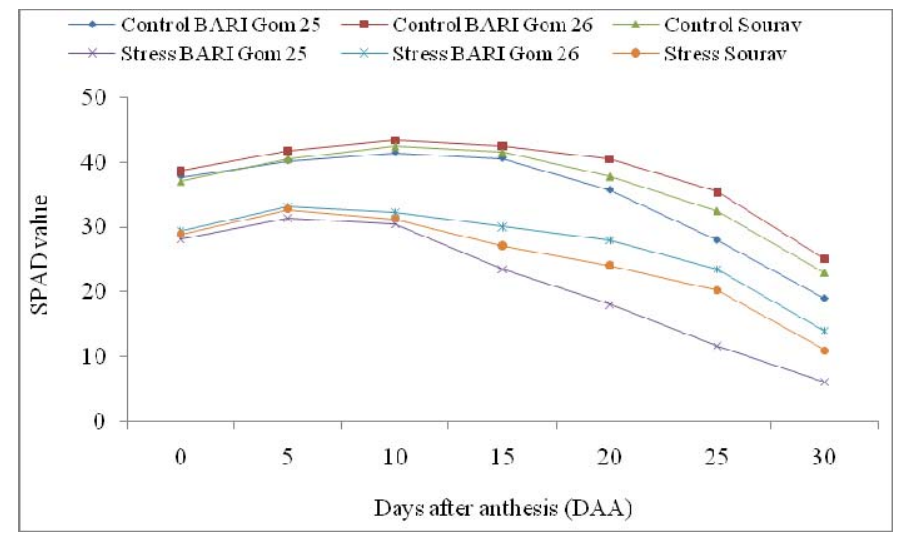

Fig. 10. Changes in flag leaf SPAD values in wheat at different growth period under variable water regimes.

\section{Yield and yield contributing attributes}

Number of effective tiller per square meter: The tiller production decreased due to water deficit and percentage of reduction varied from 9.80 to 26.50 compared to control. The highest number 
of tiller $/ \mathrm{m}^{2}$ was recorded in BARI Gom 26 and the lowest in BARI Gom 25 under both control and stress condition.

Spike length: Under control the longest spike was observed in BARI Gom $26(14.77 \mathrm{~cm})$ followed by that in Sourav $(13.27 \mathrm{~cm})$, while the shortest one in BARI Gom $25(13.19 \mathrm{~cm})$. Under water deficit condition, the longest spike was recorded in BARI Gom $26(13.50 \mathrm{~cm})$ and the shortest in BARI Gom $25(9.91 \mathrm{~cm})$.

Table 1. Number of effective tillers $/ \mathrm{m}^{2}$ and spike length in three wheat varieties as affected by water deficit stress.

\begin{tabular}{|c|c|c|c|c|c|c|}
\hline \multirow[t]{2}{*}{ Varieties } & \multicolumn{3}{|c|}{ No. of effective tillers $/ \mathrm{m}^{2}$} & \multicolumn{3}{|c|}{ Spike length $(\mathrm{cm})$} \\
\hline & Control & Stress & $\%$ reduction & Control & Stress & \% reduction \\
\hline BARI Gom 25 & 79.25 & 58.30 & 26.50 & 13.19 & 9.91 & 24.87 \\
\hline BARI Gom 26 & 86.75 & 78.30 & 9.80 & 14.77 & 13.50 & 8.6 \\
\hline Sourav & 80.50 & 67.80 & 13.30 & 13.27 & 11.45 & 13.72 \\
\hline LSD (5\%) & 21.41 & & & 0.4 & & \\
\hline CV (\%) & 3.23 & & & 4.28 & & \\
\hline
\end{tabular}

The results of the present experiment are similar some extent to the findings of Ameer et al. (2009) who reported that water stress significantly reduced the length of spike of wheat, spikelets per spike and 1000 grain-weight.

Number of spikelets per spike: The highest reduction in number of spikelets/spike was obtained in BARI Gom 25 (19.3\%), while the lowest in BARI Gom 26 (7.5\%) which was preceded by Sourav (14.08\%). The results of the present study are in agreement with the findings of Muhammad et al. (2012), who reported that the number of number of spikelets/spike number of grains/spike and harvest index (\%) in wheat were significantly increased by increasing the number of irrigation.

Table 2. Number of spikelets/spike and grains/spike in wheat varieties as affected by water deficit stress.

\begin{tabular}{lcccccccc}
\hline \multirow{2}{*}{ Varieties } & \multicolumn{3}{c}{ No. of spikelets/spike } & & \multicolumn{3}{c}{ Grains/spike } \\
\cline { 2 - 4 } \cline { 7 - 8 } \cline { 7 - 8 } & Control & Stress & \% reduction n & & Control & Stress & \% reduction \\
\hline BARI Gom 25 & 10 & 8 & 19.3 & & 28.2 & 22 & 22.0 \\
BARI Gom 26 & 12 & 11 & 7.5 & & 35.2 & 32 & 9.02 \\
Sourav & 11 & 9 & 14.8 & & 30.7 & 26 & 15.04 \\
LSD (5\%) & 3.45 & & & & 4.34 & & \\
CV (\%) & 3.23 & & & & 4.89 & & \\
\hline
\end{tabular}

Number of grains per spike: The number of grains/spike in wheat was affected markedly by water deficit stress irrespective of varieties. The highest number of grains/spike was obtained in BARI Gom 26 which was followed by Sourav and the lowest in BARI Gom 25 under control 
condition. But under water deficit condition, the highest number of grains/spike was found in BARI Gom 26 and the lowest in BARI Gom 25. The number of grains/spike under water deficit was reduced by 9.02, 15.04 and 22.00 in BARI Gom 26, Sourav and BARI Gom 25, respectively.

Table 3. Thousand grain weight and grain yield in wheat varieties as affected by water deficit stress.

\begin{tabular}{lcccccccc}
\hline \multirow{2}{*}{ Varieties } & \multicolumn{3}{c}{ 1000-grain weight $(\mathrm{g})$} & & \multicolumn{3}{c}{ Grain yield (t/ha) } \\
\cline { 2 - 4 } \cline { 6 - 8 } & Control & Stress & \% reduction n & & Control & Stress & \% reduction \\
\hline BARI Gom 25 & 43.09 & 35.61 & 17.36 & & 3.20 & 1.70 & 46.88 \\
BARI Gom 26 & 48.40 & 46.01 & 4.98 & & 3.60 & 2.80 & 19.44 \\
Sourav & 45.01 & 42.65 & 5.24 & & 3.40 & 2.50 & 26.47 \\
LSD (5\%) & 3.45 & & & & 4.34 & & \\
CV (\%) & 3.23 & & & & 4.89 & & \\
\hline
\end{tabular}

Thoushand grain weight: The highest TGW under control was found in BARI Gom 26 and the lowest in BARI Gom 25 (Table 3). Under water deficit condition the highest TGW was recorded in BARI Gom 26 followed by Sourav and the lowest in BARI Gom 25. But the reduction percentage in TGW due to water deficit stress was higher in BARI Gom 25 (17.36), whereas the reduction was comparatively low in BARI Gom 26 (4.98) followed by Sourav (5.24).

\section{Conclusion}

Under water deficit condition, the highest amount of PAR interception was recorded in BARI Gom 26 followed by Sourav and the lowest in BARI Gom 25. Water deficit decreased leaf area index (LAI), crop growth rate (CGR), relative growth rate (RGR) and net assimilation rate (NAR), effective tiller $/ \mathrm{m}^{2}$, spikelets/spike and 1000-grain weight, grain yield. However, the reduction percentage of the growth parameters and SPAD value was less in BARI Gom 26 than other two varieties. Among the three wheat varieties studied, BARI Gom 26 performed the best under water deficit conditions in relation to grain yield, light interception and SPAD value followed by Sourav and BARI Gom 25. Therefore, BARI Gom 26 may be considered for further experimentation in drought prone wheat growing regions to reconfirm the findings.

\section{References}

Akram, M. 2011. Growth and yield components of wheat under water stress on different growth stages. Bangladesh J. Agril. Res. 36(3): 455-468.

Ameer, A. M., G.S. Markhand, A.R. Mahar, S. A. Abro and N. A. Kanhar. 2009. Effect of water stress on yield and yield components of wheat (Triticum aestivum L.) varieties. Pak. J. Bot. 41(3): 1303-1310.

Bangladesh Agricultural Research Council. 2012. Fertilizer recommendation Guide.

Hussain, F., A. Khan and M. Jamal. 1987. Response of wheat genotype to water stress. Sarhad. J. Agric. 3(4): 533-542. 
Muhammad, A., M. Maqsood, A. Ali, S. W. Hassan, A. Hussain, S. Ahmad and M. A. Javed. 2012. Growth, yield components and harvest index of wheat (Triticum aestivum L.) affected by different irrigation regimes and nitrogen management strategy. Sci. Int. (Lahore) 24(2): 215-218.

Qadir, G., Saeed, M. and M. A. Cheema. 1999. Effect of water stress on growth and yield performance of four wheat cultivars. Pak. J. Biological Sci. 1: 236-239.

Qamar, R. E., M. Munir, G. Mustafa and A. Ghafar. 2011. Effect of irrigation scheduling on growth, radiation use efficiency and yield of wheat. J. Food, Agriculture \& Environment 9(1): 563-565. 2011.

Bazzaz, M. 2013. Growth, production physiology and yield in wheat under variable water regimes. Ph. D. thesis. Dept. of Agronomy. Bangabandhu Shiekh Mujibur Rahman Agricultural University, Gazipur.

Saeedipour, S. 2012. Effect of post-anthesis water deficit on yield and some physiological parameters on two wheat cultivars. African Journal of Agricultural Research 7(23): 3446-3452

(Manuscript received on 11 December, 2016; revised on 14 March, 2017) 